\title{
Platelets and Defective N-Glycosylation
}

\author{
Elmina Mammadova-Bach ${ }^{1, *}$, Jaak Jaeken ${ }^{2}$, Thomas Gudermann ${ }^{3}{ }^{(1)}$ and Attila Braun ${ }^{3, *}$
}

1 Division of Nephrology, Department of Medicine IV, Hospital of the Ludwig Maximilian University of Munich, 80336 Munich, Germany

2 Center for Metabolic Diseases, KU Leuven, 3000 Leuven, Belgium; jaak.jaeken@kuleuven.be

3 Walther-Straub-Institute for Pharmacology and Toxicology, Ludwig Maximilian University, 80336 Munich, Germany; thomas.gudermann@1rz.uni-muenchen.de

* Correspondence: elmina.bach@med.uni-muenchen.de (E.M.-B.); attila.braun@1rz.uni-muenchen.de (A.B.); Tel.: +49-89440052129 (E.M.-B.); +49-89218075720 (A.B.); Fax: +49-8940053379 (E.M.-B.); +49-89218075701 (A.B.)

Received: 15 July 2020; Accepted: 4 August 2020; Published: 6 August 2020

\begin{abstract}
N-glycans are covalently linked to an asparagine residue in a simple acceptor sequence of proteins, called a sequon. This modification is important for protein folding, enhancing thermodynamic stability, and decreasing abnormal protein aggregation within the endoplasmic reticulum (ER), for the lifetime and for the subcellular localization of proteins besides other functions. Hypoglycosylation is the hallmark of a group of rare genetic diseases called congenital disorders of glycosylation (CDG). These diseases are due to defects in glycan synthesis, processing, and attachment to proteins and lipids, thereby modifying signaling functions and metabolic pathways. Defects in $\mathrm{N}$-glycosylation and O-glycosylation constitute the largest CDG groups. Clotting and anticlotting factor defects as well as a tendency to thrombosis or bleeding have been described in CDG patients. However, N-glycosylation of platelet proteins has been poorly investigated in CDG. In this review, we highlight normal and deficient N-glycosylation of platelet-derived molecules and discuss the involvement of platelets in the congenital disorders of N-glycosylation.
\end{abstract}

Keywords: N-glycans; platelets; thrombosis; hemostasis; megakaryopoiesis; congenital disorders of N-glycosylation

\section{Introduction}

$\mathrm{N}$ (asparagine)-linked protein glycosylation is a conserved process of protein modification that eukaryotic cells use for protein folding, assembly, and trafficking. Attachment of $\mathrm{N}$-linked glycans (sugar "trees") to polypeptides takes place in the endoplasmic reticulum, where the oligosaccharyltransferase (OST) complex catalyzes the transfer of a high mannose oligosaccharide onto asparagine residues within the primary protein sequence of Asn-X-Ser or Asn-X-Thr (NXS/T), where X is any amino acid except proline [1,2]. The OST complex in humans is a protein complex composed of several subunits, including STT3 oligosaccharyltransferase complex catalytic subunit A (STT3A), subunit B (STT3B), tumor suppressor candidate 3 (TUSC3), magnesium transporter 1 (MAGT1), transmembrane protein 258 (TMEM258), keratinocyte-associated protein 2 (KCP2), ribophorins (RPN1-2), defender against cell death 1 (DAD1), oligosaccharyltransferase complex subunit 4 and 48 (OST4 and OST48), and oligosaccharyltransferase complex non-catalytic subunit (DC2) proteins [2-5] (Figure 1). So far, two OST complexes have been identified in mammalians with catalytic subunits STT3A or STT3B associated with different non-catalytic subunits [2]. They couple oligosaccharides to create a specific sugar tree on the protein surface [2]. RPNs link ribosomes to the ER surface during protein translation and present substrates to the catalytic center and additionally function as a chaperone that recognizes misfolded proteins [5,6]. STT3B is associated with the subunits MAGT1 and TUSC3, while STT3A is exclusively associated with KCP2 [7,8]. Although 90\% of N-glycosylation is generated through the 
STT3A complex, the STT3B complex frequently modifies residues with a disulfide-bonded cysteine within the amino acid motif of NCS/T, thus indicating that the function of MAGT1/TUSC 3 could be a thiol-disulfide oxidoreductase within the sequon, required for efficient $\mathrm{N}$-glycosylation. MAGT1 is also associated with calreticulin, further supporting the function of the STT3B complex in the process of N-glycosylation [7].

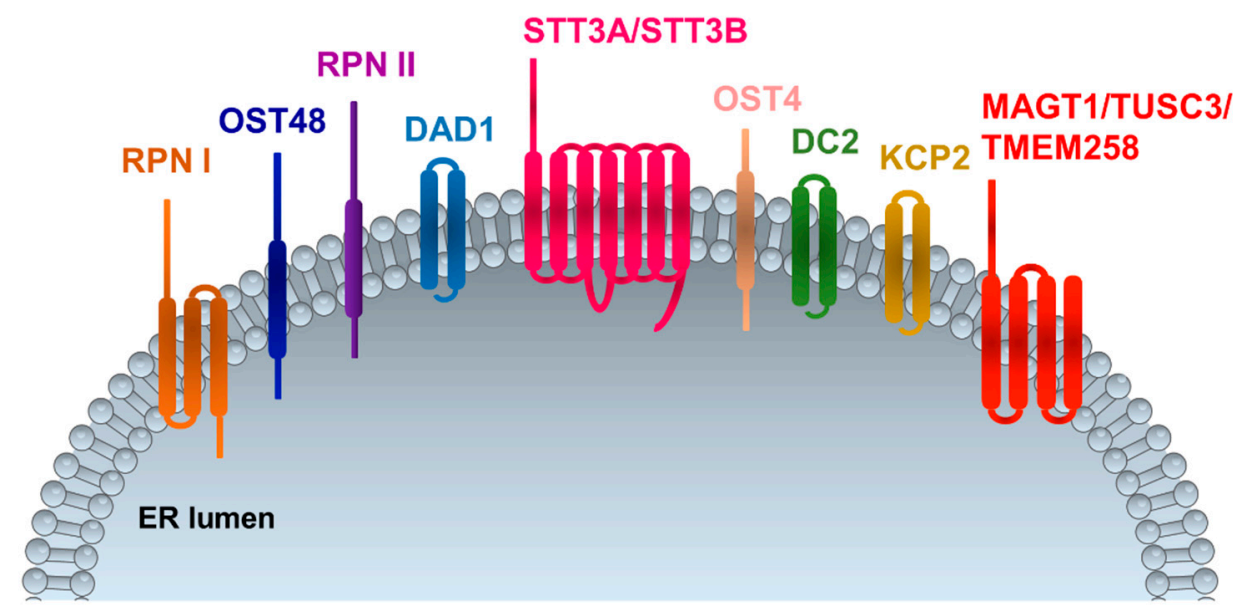

Figure 1. Oligosaccharyltransferase (OST) complex subunits in mammalians. RPNI and RPNII: ribophorin I and II; OST4 and OST48: oligosaccharyltransferase 4 and 48; DAD1: defender against cell death 1; STT3A and STT3B: oligosaccharyltransferase complex catalytic subunit A and B; DC2: oligosaccharyltransferase complex non-catalytic subunit; KCP2: keratinocyte-associated protein 2; MAGT1: magnesium transporter 1; TUSC3: tumor suppressor candidate 3; TMEM258: transmembrane protein 258. ER: endoplasmic reticulum.

Defective N-glycosylation has been observed under pathological conditions, such as cancer, inflammation, diabetes, and myocardial infarction, thus underscoring the importance of understanding the functional significance of N-glycans [9]. N-glycans in mammalians play an important role in many biological processes, such as cell adhesion, and migration by modulating functions of many cell adhesion molecules, including various glycoproteins and integrins [10]. Although several components of the OST complex exist in megakaryocytes and platelets, the functional role of the protein complex under normal and disease conditions has not been investigated. In this review, we focus on normal and deficient $\mathrm{N}$-glycosylation of platelet-derived molecules regulating several functions of platelets and megakaryocytes in thrombosis, hemostasis, and platelet biogenesis (Figure 2). We also discuss platelet involvement in the congenital disorders of N-glycosylation (N-CDG). 


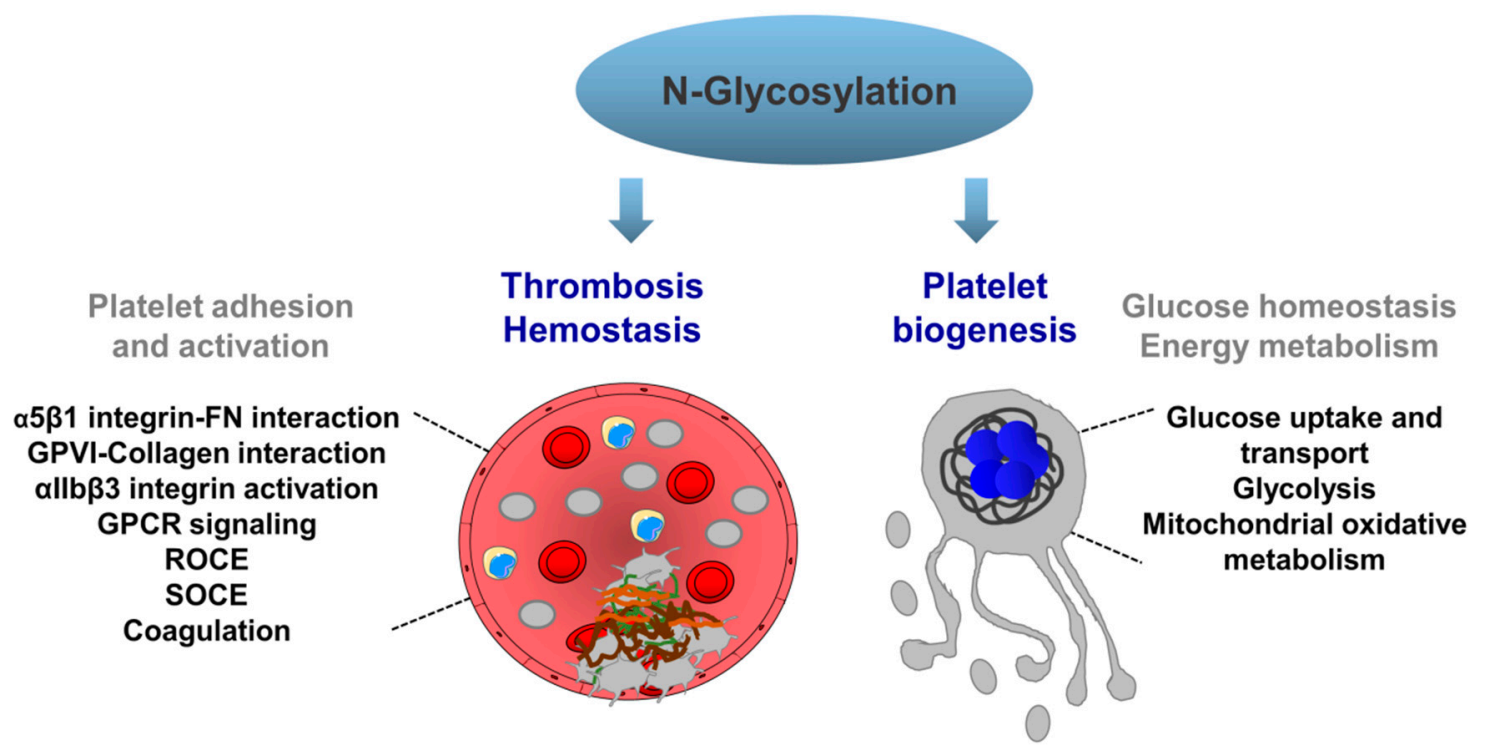

Figure 2. N-glycosylation-mediated mechanisms regulating pathophysiological functions in platelets and megakaryocytes. N-glycosylation of platelet receptors may influence platelet adhesion, activation through regulation receptor-ligand interactions, receptor processing, and signaling activation. $\mathrm{N}$-glycosylation is also involved in calcium homeostasis, ROCE and SOCE in platelets. In addition, $\mathrm{N}$-glycosylation of platelet granule proteins and coagulation factors may regulate important steps in thrombosis and hemostasis, such as granule release, platelet procoagulancy and blood clotting. Glucose uptake and transport, glycolysis mitochondrial oxidative metabolism are regulated by proteins undergoing N-glycosylation, which influence glucose homeostasis, and energy metabolism and consequently platelet biogenesis. FN: fibronectin; GPVI: Glycoprotein VI; GPCR: G-protein-coupled receptors; ROCE: receptor-operated $\mathrm{Ca}^{2+}$ entry; SOCE: store-operated $\mathrm{Ca}^{2+}$ entry.

\section{Regulation of Platelet Receptor Function by N-Glycosylation}

Platelets are small anucleated fragments derived from megakaryocytes in bone marrow sinusoids, circulating in the blood. Upon vascular injury, subendothelial matrix proteins, such as collagen are exposed to the blood flow, anchoring von-Willebrand-Factor (vWF) and initiating platelet glycoprotein (GP) Ib $\alpha-v W F$ interaction and subsequent GPVI-collagen interaction, a crucial step in platelet activation [11-14]. Activated platelets express various integrins in their active conformation. Interactions of several platelet integrins ( $\alpha \mathrm{IIb} \beta 3, \alpha \mathrm{v} \beta 3, \alpha 2 \beta 1, \alpha 5 \beta 1$, and $\alpha 6 \beta 1$ ) with their ligands (mainly fibrinogen, vitronectin, collagen, fibronectin, laminin) mediate platelet attachment to the vessel wall $[13,14]$. Upon platelet activation, different regulatory factors and secondary mediators, such as fibrinogen, $\mathrm{vWF}$, adenosine di- and triphosphate (ADP/ATP), and serotonin, stored in intracellular alpha $(\alpha)$ and dense $(\delta)$ granules, are released, which then enhance prothrombotic events and stimulate the recruitment of circulating platelets to the site of injury. After platelet accumulation at the site of vascular injury, the second wave of this hemostatic process is mediated by the blood coagulation pathway, which generates thrombin from prothrombin through the extrinsic and intrinsic pathways [15]. Thrombin converts the soluble fibrinogen to fibrin, enhancing platelet activation and aggregation responses. In addition, activated platelets expose phosphatidylserine (PS) on their surface, which then facilities the recruitment of coagulation factor complexes that stimulate generation of thrombin in other vascular cells [15]. If occurring in diseased vessels, such as atherosclerotic arteries, the same events lead to vessel occlusion, which then can result in life-threatening pathological conditions, such as myocardial infarction or ischemic stroke.

Platelet adhesion, activation, and aggregation are thus critical events in hemostasis and thrombosis and are tightly regulated by platelet glycoproteins, integrins and many other signaling receptors. Below, we discuss the effects of N-glycosylation on the function of the main platelet receptors and regulatory mechanisms controlling platelet adhesion and activation. 


\subsection{Integrins}

Loss or gain of N-glycan sites or contents may modify integrin expression and conformation, which consequently influence cell adhesion, migration, spreading, and the coagulation cascade. Integrins show much variation in the number and distribution of $\mathrm{N}$-glycosylation sites. Studies by Cai et al. highlighted the importance of $\mathrm{N}$-glycosylation on $\beta 3$ integrin ligand binding and conformational modifications [16]. By site-directed mutagenesis and structure-guided analysis in HEK293 cells, the authors showed that the N-glycan site $(\mathrm{N}) 320$ at the headpiece and leg domain of the integrin $\beta 3$ interface positively regulates $\alpha \mathrm{IIb} \beta 3$ integrin activation [16]. In addition to this glycan site, $\beta 3-\mathrm{N} 559$ at the $\beta 3$-I-EGF3 and $\alpha$ Ilb-calf- 1 domain interface, and the $\beta 3-N 654$ at the $\beta 3-\beta$-tail and $\alpha$ Ilb-calf- 2 domain interface positively regulate the activation of both $\alpha \operatorname{IIb} \beta 3$ and $\alpha \mathrm{V} \beta 3$ integrins [16]. Deletion of the $\beta 3$-N371 glycan, located near the $\beta 3$ hybrid and I-EGF3 interface, or $\beta 3-N 452$ in the I-EGF1 domain could enhance $\beta 3$ integrin activation [16]. Interestingly, $\mathrm{N}$-glycosylation at the $\beta I$ domain of $\beta 1$ subunit ( $\beta 1-\mathrm{N} 343$ ) negatively regulates fibronectin (FN) binding and $\alpha 5 \beta 1$ integrin activation [16]. Taken together, these data suggest that $\mathrm{N}$-glycans may either positively or negatively modify ligand binding and integrin activation. $\mathrm{N}$-glycosylation sites have also been found on human platelet $\alpha 2$ and $\alpha 6$ integrins [17], but their physiological role has not been investigated.

\subsection{Glycoprotein VI}

Glycoprotein VI (GPVI) is one of the major collagen receptors in platelets, but it also interacts with other extracellular matrix molecules, such as laminin and fibrin [18-22]. GPVI signals through an immunoreceptor tyrosine-based activation motif (ITAM) and regulates diverse physiological processes in platelets including adhesion, activation, aggregation, and procoagulant activity $[23,24]$. In stably transfected DAMI megakaryocyte-like cell line, GPVI amino acid substitutions at position N92 or N94 resulted in a $90 \%$ or greater decrease in cell adhesion to the collagen-related peptide (CRP) and a $65 \%$ to $70 \%$ decrease to collagen [25]. These mutations do not affect protein expression or subcellular localization of GPVI, indicating that N-linked glycosylation of GPVI contributes to maximal adhesion to collagen or CRP [25]. Circulating platelets have stable levels of GPVI on their surfaces, but GPVI can undergo rapid proteolytic cleavage, generating soluble GPVI in the blood plasma. The shedding process is induced by GPVI ligands, such as collagen, fibrin, and venom toxins, or by elevated shear stress and active Factor Xa (FXa) [26]. GPVI can also be cleaved by disintegrin and metalloproteases ADAM10 and ADAM17 [26,27]. ADAM10 contains several potential N-glycosylation sites (N267, N278, N439, and N551) [28]. Mutation of N267, N439, and N551 did not completely abolish enzymatic activity of the ADAM10; however, reduced levels were found [28]. These results suggest that N-glycosylation can regulate ADAM10 function, resistance to proteolysis, and maintenance of the enzymatic activity.

\subsection{C-Type Lectin-Like Receptor 2}

The C-type lectin-like receptor 2 (CLEC-2) has been identified as an important platelet (hem)ITAM receptor, implicated in diverse platelet functions, although the natural ligands of this platelet receptor are still under investigation [29]. In platelet lysates, CLEC-2 is detected in two molecular masses, which are differently glycosylated. A specific glycosylation site is present on N134 [30], but its physiological role in platelet activation has not been further investigated.

\subsection{GPIb-IX-V Complex}

The glycoprotein (GP) Ib-IX-V complex mediates vWF-dependent platelet adhesion at sites of blood vessel injury $[13,31]$. Molecular defects of this receptor complex account for the Bernard-Soulier syndrome (BSS). BSS variants show a decrease of GPIb $\alpha$ size and expression on the platelet surface [32]. Often, the receptor complex associates normally but displays defective processing of its $\mathrm{N}$-linked glycans and abnormal O-glycosylation of GPIb $\alpha$ [33]. Confocal immunofluorescence microscopy reveals that mutant complexes mainly accumulate in the ER, whereas only a small proportion of the 
residual protein is successfully transported to the platelet surface [33]. In 2003, Hoffmeister et al. showed a major role of GPIb $\alpha$ in the clearance of cooled platelets [34]. Cold storage-induced clustering of GPIb $\alpha$ on the surface of murine platelets leads to the recognition of GPIb $\alpha$ by the $\alpha \mathrm{M} \beta 2$ integrin of macrophages [34]. Later, these researchers showed that exposed $\mathrm{N}$-acetyl-D-glucosamine (GlcNAc) residues, present on N-linked GPIb $\alpha$ glycans, caused $\alpha \mathrm{M} \beta 2$ integrin recognition [35].

Another subunit of the complex, glycoprotein V (GPV), contains a single transmembrane domain, a short cytoplasmic domain, and a large extracellular domain with 8 potential N-glycosylation sites [36]. Mouse and human glycoprotein IX (GPIX) share 71\% identical amino acids with highly conserved cysteine residues and a putative N-linked glycosylation site as well, located at residue N44 [37-39]. However, the physiological role of GPIX N-glycosylation has not been investigated in platelets.

\subsection{G-Protein-Coupled Receptors}

Thrombus growth requires mediators such as ADP, thromboxane A2 (TxA2), and thrombin, which act through G-protein-coupled receptors (GPCR). Platelet activation through GPCRs involves three major signaling pathways, initiated by the activation of $G \alpha_{q}, G \alpha_{13}$, and $G \alpha_{i}$ proteins [40,41]. Platelet activation by ADP is mediated by the $\mathrm{G} \alpha_{\mathrm{q}}$-coupled P2Y $\mathrm{Y}_{1}$ and the $\mathrm{G} \alpha_{\mathrm{i}}$-coupled $\mathrm{P} 2 \mathrm{Y}_{12}$ receptor, resulting in the inhibition of activated adenylyl cyclase [42-44]. Platelets from $\mathrm{P}_{2} \mathrm{Y}_{1}$-deficient mice do not undergo the usually observed shape change in response to ADP, and ADP-induced aggregation is severely impaired $[45,46]$. Moreover, mildly increased bleeding times and a relative resistance to ADP-induced thromboembolism has been observed for mice carrying a genetic deletion for the $\mathrm{P}_{2} \mathrm{Y}_{1}$ receptor $[45,46]$. Platelets from $\mathrm{P}_{2} \mathrm{Y}_{12}$-deficient mice have a normal shape change but impaired aggregation in response to ADP and prolonged bleeding time, and they form smaller and unstable thrombi $[47,48]$. The $\mathrm{P}_{2} \mathrm{Y}_{12}$ receptor contains two $\mathrm{N}$-glycosylation sites in its extracellular $\mathrm{N}$-terminus. Interestingly, $\mathrm{N}$-glycosylation is dispensable for surface expression and ligand binding activity of the receptor, although non-glycosylated $\mathrm{P}_{2} \mathrm{Y}_{12}$ receptors are defective in the $\mathrm{P}_{2} \mathrm{Y}_{12}$-mediated inhibition of adenylyl cyclase activity, demonstrating the role of N-linked glycans in receptor signaling [49].

Protease-activated receptor (PAR) is also a member of GPCR receptors (GPCRs), playing a major role in thrombin-mediated platelet responses [50-52]. Activation of platelets by thrombin is essentially mediated by PARs, which couple to $G \alpha_{\mathrm{q}}$ and $\mathrm{G} \alpha_{12} / \mathrm{G}_{13}$ proteins [50,51]. Of the four PAR receptors, human platelets express PAR1 and PAR4, whereas mouse platelets express PAR3 and PAR4. PAR1 and PAR3 contain a hirudin-like domain, which has a high-affinity thrombin binding site. This interaction enables thrombin to bind and activate PAR receptors, resulting in cleavage [52]. The second extracellular loop (ECL2) of the PAR1 receptor is critical for specific ligand interactions and agonist recognition. PAR1 and ECL2 also contain two N-glycosylation sites, while the PAR2 isoform contains a single $\mathrm{N}$-linked glycosylation site [53]. It has been shown that N-glycosylation of PAR1 at the surface of ECL2 influences ligand docking interactions that enhance the stabilization of the activated receptor complex and activation of $G$ protein signaling [53].

\section{Regulation of Calcium Homeostasis by N-Glycosylation}

Calcium $\left(\mathrm{Ca}^{2+}\right)$ homeostasis plays a crucial role in the regulation of platelet shape change, adhesion, activation, platelet granule release, and thrombus growth. Most platelet-activating receptors act through stimulation of phospholipase C (PLC) isoforms, catalyzing the hydrolysis of phosphatidyl 4,5-biphosphate ( $\mathrm{PIP}_{2}$ ) into diacylglycerol (DAG) and inositol 1,4,5-triphosphate $\left(\mathrm{IP}_{3}\right)[54,55]$. These second messengers control receptor and store-operated $\mathrm{Ca}^{2+}$ entry (ROCE and SOCE). $\mathrm{IP}_{3}$ induces the depletion of the $\mathrm{ER} \mathrm{Ca}^{2+}$ stores through the $\mathrm{IP}_{3}$-receptor $\left(\mathrm{IP}_{3} \mathrm{R}\right)$, which are integral membrane proteins of the ER, while DAG regulates $\mathrm{Ca}^{2+}$ entry through protein kinase $\mathrm{C}$ and activation of DAG-sensitive $\mathrm{Ca}^{2+}$ channels [55]. The receptor-induced $\mathrm{Ca}^{2+}$ entry mechanisms are mediated by ATP-gated $\mathrm{P}_{2} \mathrm{X}_{1}$ channel and DAG-regulated transient receptor potential channel 6 (TRPC6) $[55,56]$. 
P2X $X_{1}$ channel function has been well described in immune cells and platelets and contributes to thrombosis $[57,58]$. Drugs targeting the $\mathrm{P} 2 \mathrm{X}_{1}$ receptor function have been proposed for the development of anti-thrombotic agents [42,43,57]. The role of $\mathrm{N}$-glycans for $\mathrm{P}_{2} \mathrm{X}_{1}$ assembly, surface expression, and ligand recognition was analyzed using site-directed mutagenesis in Xenopus oocytes [59]. In this study, two out of the four naturally occurring $\mathrm{N}$-glycans were sufficient for functional expression of $\mathrm{P} 2 \mathrm{X}_{1}$ receptors at the cell surface, and residue N210 contributed to ATP potency [59].

Rat P2X $X_{1}$ contains five putative $\mathrm{N}$-glycosylation sites which are all located in the ectodomain [59]. The N242 residue is absent in humans but not in the rat [59], indicating species-specific glycosylation of $\mathrm{P} \mathrm{X}_{1}$ in mammalians. Endo $\mathrm{H}$ treatment removes glycosylation chains, thereby reducing the molecular weight of $\mathrm{P} 2 \mathrm{X}_{1}$. This is further reduced by PNGase treatment, indicating that $\mathrm{P} 2 \mathrm{X}_{1}$ is glycosylated in the ER lumen and further in the Golgi [60]. Interestingly, mutations of residues N153, N184, and N242 did not affect ATP-mediated activation of P2X 1 [60]. Residue F185 has been proposed to be involved in ATP binding, and N184 is located in this consensus motif [60]. N153, N184, and N242 are also glycosylated in human platelets, but their physiological function has not been investigated [17].

TRPC6 is highly expressed in both mouse and human smooth muscle cells, megakaryocytes, and platelets [61-63], and its activation is strongly dependent on PLC- and phospholipase D (PLD)-mediated DAG production [55]. By using site-directed mutagenesis in HEK293 cells, Dietrich et al. showed that elimination of the distal glycosylation site at N561 residue converted the tightly regulated TRPC6 into a constitutively active channel [64].

SOCE is the major $\mathrm{Ca}^{2+}$ entry route in activated platelets $[54,55,65]$. ER-resident $\mathrm{Ca}^{2+}$ is depleted to the cytoplasm, leading to activation of the stromal interaction molecule 1 (STIM1), which is the principal regulator of SOCE in platelets $[54,55,66]$; activated STIM1 is subsequently translocated from the ER to the plasma membrane-resident Orai1 channel $[54,65,67]$. Consequently, cytosolic $\mathrm{Ca}^{2+}$ levels are increased, mediating several physiological processes, including degranulation, integrin activation, and platelet aggregation $[54,55,65]$. The EF-hand domain of STIM1 is located in the ER lumen, and can be glycosylated at residues N131 and N171 [68]. It has been proposed that STIM1 N-glycans may modify the $\mathrm{Ca}^{2+}$ binding affinity of the molecule, as well as membrane stability and oligomerization with Orai1 [68]. In line with this notion, site-directed mutagenesis of the indicated N-glycosylation sites on STIM1 resulted in abolished SOCE in mammalian cells [68].

\section{Regulation of Energy Metabolism by N-glycosylation}

Platelet shape change and aggregation require a high concentration of ATP, which is stored and released by $\delta$-granules upon platelet activation [15]. Platelets also possess the molecular machinery necessary to generate ATP through glycolysis and oxidative phosphorylation (OXPHOS) of glucose $[69,70]$. Platelets express several transporters of glucose and also can take up and oxidize fatty acids and glutamine as an alternative source of ATP generation $[69,70]$. Glucose transporters (GLUTs) are encoded by the solute carrier 2a (Slc2a) genes, transporting glucose through the plasma membranes of megakaryocytes and platelets [71,72]. Depending on the actual blood glucose concentrations, expression levels of GLUTs on the cell surface are either increased or reduced to maintain the basal glucose levels within the cells. Recently, a reduced platelet count has been detected in Slc2a1 ${ }^{--} / \mathrm{Slc} 2 a 3^{--}$double knockout mice with a combination of impaired pro-platelet formation and increased clearance of circulating platelets [73]. Interestingly, glucose uptake was completely blocked in $S l c 2 a 1^{--} / S l c 2 a 3^{--}$platelets, but mitochondria were able to take up alternative substrates to maintain energy metabolism. When mitochondrial function was further inhibited, Slc2a1 ${ }^{-1} / S l c 2 \mathrm{ab}^{--}$ mice became severely thrombocytopenic, highlighting the important role of mitochondria in platelet production when glycolysis is severely impaired [73].

$\mathrm{N}$-glycosylation regulates the binding affinity of GLUT1 to glucose and hence glucose uptake and transport [74-77]. Recently, quantitative glycoproteomics data and pulse-labeling experiments showed that the N45 residue of GLUT1 is N-glycosylated by the STT3B complex [78]. GLUT1 is hypo-glycosylated in lymphocytes, isolated from X-linked immunodeficiency with magnesium 
defect (XMEN) patients, and this (hypoglycosylation/reduced glycosylation of GLUT1) was also observed in $\mathrm{Magt}^{-/-} \mathrm{Tusc}^{-/-}$and $\mathrm{Stt} 3 \mathrm{~b}^{-/-}$HEK293 cell lines, indicating an important regulatory role of MAGT1 in N-glycosylation of GLUT1 during glucose uptake [78,79]. It is important to note that the glycosylation defects in XMEN lymphocytes are due to the absence of TUSC3 gene expression, the alternative compensatory mechanism of MAGT1 function [78]. More recently, Matsuda-Lennikov et al. also showed that MAGT1 function is partly interchangeable with TUSC3, but each protein has a different tissue distribution in humans [80]. The blood plasma of XMEN patients contains hypo-glycosylated haptoglobin, hemoglobin, and immunoglobulin heavy chain, which are regulatory elements of iron metabolism [80]. Therefore, such defects in N-glycosylation may also alter ATP transport and energy metabolism.

It has also been shown that STIM1-mediated SOCE and also calcineurin regulate the levels of GLUT1 and GLUT3, thereby influencing the efficiency of glycolysis [81]. Indeed, impaired $\mathrm{Ca}^{2+}$ influx through SOCE strongly inhibited the mRNA expression of glycolytic and mitochondrial enzymes in STIM1/2-deficient T lymphocytes [81]. In megakaryocytes and platelets, further investigation is necessary to understand the role of TUSC3, MAGT1, STIMs, and SOCE in the regulation of energy metabolic pathways by $\mathrm{N}$-glycosylation and protein expression of GLUTs.

\section{Regulation of The Coagulation Pathways by N-Glycosylation}

$\alpha$-Granules are the most abundant granules in platelets; their contents include adhesive glycoproteins, fibrinogen, vWF, coagulation factors, and granule membrane-specific proteins such as P-selectin [15,82]. Intracellular $\mathrm{Ca}^{2+}$ mobilization and granule release are essential steps to increase the procoagulant activity of platelets and to modulate the coagulation cascade [82]. Therefore, the modification of N-glycan composition on the platelet surface might be involved in the regulation of hemostasis and the coagulation cascade.

P-selectin has two molecular sizes in platelets, and the high molecular weight form can be digested by peptide $\mathrm{N}$-glycosidase $\mathrm{F}$. The $\mathrm{N}$-glycosylation inhibitor tunicamycin can suppress the surface expression of P-selectin, indicating a critical role of $\mathrm{N}$-glycosylation in P-selectin trafficking [83]. Thrombin-stimulated platelets do expose P-selectin on the platelet surface and induce the phosphorylation of serine/threonine kinase 1 (AKT), but tunicamycin can inhibit this signaling event, suggesting that AKT signaling is involved in the tunicamycin-mediated inhibition of P-selectin expression [83].

Antithrombin III is a member of the serine protease inhibitor family. It is involved in the regulation of blood coagulation by inactivating several serine proteases and plasma factors, including thrombin, factor IXa, Xa, XIa, and XIIa [84]. Heparin enhances antithrombin III function; therefore antithrombin III deficiency or reduced heparin binding are involved in prothrombotic disorders [85]. Antithrombin III contains several putative N-glycosylation sites, namely N128, N167, N187, and N224 [86,87]. In antithrombin III deficiency, it has not been shown whether altered N-glycosylation may influence the heparin-binding of this serine protease inhibitor [87].

Histidine-rich glycoprotein (HRG) is mainly produced in the liver. It is involved in the regulation of immunity, coagulation, and angiogenesis and interacts with several plasma proteins and receptors in the blood. High levels of HRG are associated with symptoms of various cardiovascular disorders, while congenital deficiency of HRG results in thrombophilia in humans [88,89]. Three N-glycosylation sites have been confirmed in HRG, namely at N63, N125, and N344. A common human polymorphism has been described as well, creating a new glycosylation site at N202 [87]. However, so far, no reports have been published about the glycosylation status of HRG in the context of thrombotic disease or hemostasis.

Kininogen or Fitzgerald factor (KNG) is mainly synthesized in the liver and exists in two molecular weights. It is expected to be highly glycosylated, based on the large $\mathrm{N}$ - and O-glycan structures, as the observed protein mass is more than $40 \mathrm{kDa}$ higher than the mass calculated from the amino acid sequence $[87,90]$. The intact form of KNG is a cysteine proteinase inhibitor and has a major role in 
blood coagulation and inflammatory responses [91]. Depending on the physiological status of the blood, it can be cleaved into six different subchains which have diverse functions in the body [91]. KNG has four N-linked glycosylation sites at residues of N48, N169, N205, and N294 [87]. However, the effect of N-glycans on KNG function has not been investigated.

Coagulation factor VII (FVII) has two N-glycosylation sites (N145 and N322). In transiently transfected COS-7 cells, mutations of these sites reduce the release of FVII to the medium and induce partial protein degradation $[92,93]$. These observations suggest an important role of $\mathrm{N}$-glycans in the intracellular stability of the protein.

Coagulation factor XI is a disulfide-linked homodimer zymogen. Its deficiency causes bleeding diathesis in humans, referred to as hemophilia C [94]. N-glycosylation sites have been identified in both heavy (N72, N108, N145) and light chains (N432, N473) [95].

vWF is a key component of the coagulation cascade, acting as a bridging protein between the coagulant factors and platelet GPIb receptor, thereby mediating platelet adhesion at sites of vascular injury. Glycomics analysis of vWF showed about 100 distinct N-glycan structures [96]. Site-directed mutagenesis studies showed that individual glycans N99 (D1 domain), N857 (D' domain), N2400 (B1 domain), and N2790 (CK domain) are critical for vWF synthesis and expression [97]. vWF becomes conformationally unfolded by shear stress in the circulation when it is cleaved by disintegrin and metalloprotease with thrombospondin type I repeats-13 (ADAMTS13) [98]. In a mutagenesis assay, N1574 glycan from isolated recombinant vWF-A2 domain increased the interaction of vWF with ADAMST13 and enhanced the susceptibility of vWF to ADAMTS13 proteolysis [99]. N-glycosylation contributes to VWF cleaving activity of ADAMTS13 by creating a conformational change of this protease optimal for interaction with vWF multimers [100]. However, once secreted, ADAMTS13 does not require $\mathrm{N}$-glycans for its vWF cleaving activity [100].

\section{Platelets in Congenital Disorders of N-Glycosylation}

Congenital disorders of glycosylation (CDG) are a rapidly expanding group of genetic disorders due to defects in glycoprotein and glycolipid glycan assembly and attachment [101,102]. Since the first clinical report in 1980, approximately 130 different CDG have been identified. Most of them have an autosomal recessive inheritance. They can be divided into different subgroups: (I) defects in protein $\mathrm{N}$-glycosylation (N-CDG), (II) defects in protein O-glycosylation, (III) combined protein glycosylation defects, (IV) lipid glycosylation defects, and (V) glycosylphosphatidylinositol anchor synthesis defects. Here, we review data on abnormal blood platelet number and function in N-CDG. It is important to note that platelet abnormalities, mainly thrombocytopenia, are mentioned only in a small group of N-CDG in the literature. On the other hand, in CDG patients with nonimmune hydrops fetalis, thrombocytopenia was reported in 53\% (9/17) of patients, all in N-CDG patients, except one family with deficiency of subunit 6 of the conserved oligomeric Golgi complex (COG6)-CDG [103].

ALG1-CDG is due to deficiency of 1,4-mannosyltransferase 1, resulting mainly in a neurological syndrome, associated with variable involvement of other organs. Hematological abnormalities were found in $50 \%$ of these patients. These included thrombocytopenia (5/18 tested patients) besides general coagulation abnormalities and protein $C$ and protein $S$ deficiency [104].

ALG8-CDG patients are characterized by defective $\alpha-1,3$-glucosyltransferase function. It is a severe disease since most patients died within the first year of life. Most patients showed prematurity, edema, dysmorphism, and gastrointestinal and cognitive impairment. In addition, coagulopathy and thrombocytopenia were noticed in the patients tested, but detailed platelet analyses have not been reported $[105,106]$.

MAGT1-CDG results in X-linked immunodeficiency with $\mathrm{Mg}^{2+}$ defect, Epstein-Barr virus (EBV) infection, and neoplasia, called XMEN syndrome [107]. At the same time, it is also a defect in N-glycosylation since MAGT1 is an OST component [78]. Most patients developed chronic EBV-associated B cell lymphomas, caused by altered $\mathrm{Mg}^{2+}$ homeostasis in T-helper, cytotoxic T-lymphocytes, and natural killer (NK) cells $[108,109]$. Recently, Blommaert et al. reported new 
MAGT1-CDG patients with immunodeficiency and, in addition, developmental disability and hypoglycosylation [78]. MAGT1-mediated $\mathrm{Mg}^{2+}$ transport and its signaling has been proposed to act on the activation of PLC and subsequent intracellular $\mathrm{Ca}^{2+}$ release from the $\mathrm{IP}_{3}$-sensitive $\mathrm{Ca}^{2+}$ store [107]. In MAGT1-deficient cells, $\mathrm{Mg}^{2+}$ supplementation increased the free intracellular $\mathrm{Mg}^{2+}$ levels, most likely through Transient receptor potential cation channel subfamily $\mathrm{M}$ member 7 (TRPM7), TUSC3, or other alternative $\mathrm{Mg}^{2+}$ transport mechanisms [110,111]. Interestingly, $\mathrm{Mg}^{2+}$ supplementation effectively decreased EBV viremia in human patients after short-term treatment [112]; the effects of long-term treatment are not known. Recently, it has been shown that MAGT1-dependent glycosylation is sensitive to $\mathrm{Mg}^{2+}$ levels, and that reduced $\mathrm{Mg}^{2+}$ impairs immune cell function via the loss of specific glycoproteins, i.e., CD28 [80]. Most XMEN patients develop mild to moderate thrombocytopenia [112,113], although a detailed description of megakaryocyte and platelet functions have not been reported yet. Magt ${ }^{-l y}$ mice have normal platelet count and size, although an altered ploidy of megakaryocytes was detected; but this mild defect did not influence platelet production [114]. $\mathrm{Mg}^{2+}$ is a known natural "platelet antagonist", since elevated cytoplasmic $\mathrm{Mg}^{2+}$ concentrations $\left(\left[\mathrm{Mg}^{2+}\right]_{\mathrm{i}}\right)$ inhibit platelet aggregation, cyclooxygenase activity, and TxA2 release [115]. Although many in vitro studies highlighted the effect of $\mathrm{Mg}^{2+}$ on hemostasis and coagulation, the regulatory roles of MAGT1 or other $\mathrm{Mg}^{2+}$ effectors and transporters in mouse models are still unknown.

MPI-CDG is a defect in mannose phosphate isomerase (MPI) that catalyzes the interconversion of fructose 6-phosphate and mannose 6-phosphate. It plays a critical role in maintaining the supply of D-mannose derivatives required for most glycosylation reactions [116]. MPI-CDG patients show a hepatic-intestinal presentation including thromboses besides life-threatening gastrointestinal bleeding. It is one of the very few treatable CDG with oral mannose supplements or liver transplantation [116]. Thrombocytopenia, as part of pancytopenia, has been reported in an adult, but no follow-up on platelet levels has been reported [117].

PMM2-CDG is a defect in phosphomannomutase 2 (PMM2) that catalyzes the isomerization of mannose 6-phosphate to mannose 1-phosphate. Subsequently, mannose-1-phosphate is converted into GDP-mannose, the source of mannose for the growing oligosaccharide chain. It is by far the most common N-glycosylation disorder and a multisystem disease with a highly variable phenotype. Characteristic clinical features are inverted nipples and peculiar fat pads [118]. These patients predominantly show a thrombotic tendency [118]. Platelets isolated from PMM2-CDG patients could aggregate spontaneously in platelet-rich plasma and at stirring conditions; the disappearance of single platelets was faster in whole blood. However, the platelet N-glycoproteome in PMM2-CDG patients showed unaltered N-glycosylation profiles of major platelet surface molecules, suggesting different mechanisms involved in hyperactivation of PMM2-CDG platelets [119]. Further studies are necessary to identify the molecular mechanisms, leading to thrombotic complications in these patients.

SLC35A1-CDG is a defect in the cytidine $5^{\prime}$-monophosphate (CMP)-sialic acid transporter that transfers sialic acid to the medial- and trans-Golgi. Patients show a neurological phenotype and bleeding diathesis associated with macrothrombocytopenia. Bone marrow aspirate of patients showed an increased megakaryocyte count with a predominance of immature forms. Evidence was found for a very short platelet life span as well [120-122]. A mouse model lacking specifically Slc35a1 in megakaryocytes showed thrombocytopenia, decreased megakaryocyte maturation, and increased platelet clearance [123].

STT3A-CDG is a defect in a catalytic subunit of the OST complex. Patients show a neurological phenotype and exhibit severely decreased factor VIII (FVIII) secretion and lower plasma vWF level. Among seven patients, one had a mild thrombocytopenia, and one had normal platelet levels, and in the others there was no information on the platelet number [124].

\section{Conclusions}

A rather small number of studies have investigated the effects of defective $\mathrm{N}$-glycosylation on platelet functions, and the pathophysiological role(s) of N-glycosylation in megakaryocyte/platelet 
functions remain(s) largely unknown. Studies using mouse models, e.g., with deficiency of OST complex components, are needed to clarify these issues. It would be interesting to investigate how far thrombocytopenia, coagulation defects, and thrombotic complications observed in CDG patients are a direct consequence of defective N-glycosylation in megakaryocytes/platelets.

Author Contributions: E.M.-B. and A.B. wrote the manuscript; J.J. and T.G. critically reviewed the manuscript and contributed to the writing. All authors have read and agreed to the published version of the manuscript.

Funding: A.B. is funded by the Deutsche Forschungsgemeinschaft (DFG, German Research Foundation, Projektnummer 374031971, TRR 240/A09). T.G. is supported by the Deutsche Forschungsgemeinschaft (DFG, German Research Foundation, Transregional Collaborative Research Center TRR 152 and Research Training Group 2338).

Acknowledgments: We would like to thank Ingrid Boekhoff (Walther-Straub-Institute for Pharmacology and Toxicology, Ludwig Maximilian University, Munich, Germany) for critically reading the manuscript.

Conflicts of Interest: The authors declare no conflict of interest.

\section{References}

1. Harada, Y.; Ohkawa, Y.; Kizuka, Y.; Taniguchi, N. Oligosaccharyltransferase: A gatekeeper of health and tumor progression. Int. J. Mol. Sci. 2019, 20, 6074. [CrossRef]

2. Mohanty, S.; Chaudhary, B.P.; Zoetewey, D. Structural insight into the mechanism of N-linked Glycosylation by Oligosaccharyltransferase. Biomolecules 2020, 10, 624. [CrossRef] [PubMed]

3. Yu, X.; Zhai, C.; Fan, Y.; Zhang, J.; Liang, N.; Liu, F.; Cao, L.; Wang, J.; Du, J. TUSC3: A novel tumour suppressor gene and its functional implications. J. Cell. Mol. Med. 2017, 21, 1711-1718. [CrossRef] [PubMed]

4. Shibatani, T.; David, L.L.; McCormack, A.L.; Frueh, K.; Skach, W.R. Proteomic analysis of mammalian oligosaccharyltransferase reveals multiple subcomplexes that contain Sec61, TRAP, and two potential new subunits. Biochemistry 2005, 44, 5982-5992. [CrossRef] [PubMed]

5. Kelleher, D.J.; Karaoglu, D.; Mandon, E.C.; Gilmore, R. Oligosaccharyltransferase isoforms that contain different catalytic STT3 subunits have distinct enzymatic properties. Mol. Cell 2003, 12, 101-111. [CrossRef]

6. Wilson, C.M.; Roebuck, Q. High, ribophorin I regulates substrate delivery to the oligosaccharyltransferase core. Proc. Natl. Acad. Sci. USA 2008, 105, 9534-9539. [CrossRef]

7. Cherepanova, N.A.; Shrimal, S.; Gilmore, V. Oxidoreductase activity is necessary for N-glycosylation of cysteine-proximal acceptor sites in glycoproteins. J. Cell Biol. 2014, 206, 525-539. [CrossRef]

8. Shrimal, S.; Cherepanova, N.A.; Gilmore, V. DC2 and KCP2 mediate the interaction between the oligosaccharyltransferase and the ER translocon. J. Cell Biol. 2017, 216, 3625-3638. [CrossRef]

9. Reily, C.; Stewart, T.J.; Renfrow, M.B.; Novak, J. Glycosylation in health and disease. Nat. Rev. Nephrol. 2019, 15, 346-366. [CrossRef]

10. Gu, J.; Taniguchi, N. Potential of N-glycan in cell adhesion and migration as either a positive or negative regulator. Cell Adhes. Migr. 2008, 2, 243-245. [CrossRef]

11. Scharf, R.E. Platelet signaling in primary haemostasis and arterial thrombus formation: Part 2. Hämostaseologie 2018, 38, 211-222. [PubMed]

12. Scharf, R.E. Platelet signaling in primary haemostasis and arterial thrombus formation: Part 1. Hämostaseologie 2018, 38, 203-210. [PubMed]

13. Xu, X.R.; Carrim, N.; Neves, M.A.; McKeown, T.; Stratton, T.W.; Coelho, R.M.; Lei, X.; Chen, P.; Xu, J.; Dai, X.; et al. Platelets and platelet adhesion molecules: Novel mechanisms of thrombosis and anti-thrombotic therapies. Thromb. J. 2016, 14, 29. [CrossRef] [PubMed]

14. Jackson, S.P. Arterial thrombosis-insidious, unpredictable and deadly. Nat. Med. 2011, 17, 1423-1436. [CrossRef]

15. Golebiewska, E.M.; Poole, A.W. Platelet secretion: From haemostasis to wound healing and beyond. Blood Rev. 2014, 29, 153-162. [CrossRef] [PubMed]

16. Cai, X.; Thinn, A.M.M.; Wang, Z.; Shan, H.; Zhu, J. The importance of N-glycosylation on beta3 integrin ligand binding and conformational regulation. Sci. Rep. 2017, 7, 4656. [CrossRef]

17. Lewandrowski, U.; Lohrig, K.; Zahedi, R.P.; Wolters, D.; Sickmann, A. Glycosylation site analysis of human platelets by electrostatic repulsion hydrophilic interaction chromatography. Clin. Proteom. 2008, 4, 25-36. [CrossRef] 
18. Mammadova-Bach, E.; Ollivier, V.; Loyau, S.; Schaff, M.; Dumont, B.; Favier, R.; Freyburger, G.; Latger-Cannard, V.; Nieswandt, B.; Gachet, C.; et al. Platelet glycoprotein VI binds to polymerized fibrin and promotes thrombin generation. Blood 2015, 126, 683-691. [CrossRef]

19. Clemetson, J.M.; Polgar, J.; Magnenat, E.; Wells, T.N.; Clemetson, K.J. The platelet collagen receptor glycoprotein VI is a member of the immunoglobulin superfamily closely related to FcalphaR and the natural killer receptors. J. Biol. Chem. 1999, 274, 29019-29024. [CrossRef]

20. Alshehri, O.M.; Hughes, C.E.; Montague, S.; Watson, S.K.; Frampton, J.; Bender, M.; Watson, S.P. Fibrin activates GPVI in human and mouse platelets. Blood 2015, 126. [CrossRef]

21. Inoue, O.; Suzuki-Inoue, K.; McCarty, O.J.; Moroi, M.; Ruggeri, Z.M.; Kunicki, T.J.; Ozaki, Y.; Watson, S.P. Laminin stimulates spreading of platelets through integrin alpha6beta1-dependent activation of GPVI. Blood 2006, 107, 1405-1412. [CrossRef]

22. Induruwa, I.; Moroi, M.; Bonna, A.; Malcor, J.D.; Howes, J.M.; Warburton, E.A.; Farndale, R.W.; Jung, S.M. Platelet collagen receptor Glycoprotein VI-dimer recognizes fibrinogen and fibrin through their D-domains, contributing to platelet adhesion and activation during thrombus formation. J. Thromb. Haemost. 2018, 16, 389-404. [CrossRef] [PubMed]

23. Zahid, M.; Mangin, P.; Loyau, S.; Hechler, B.; Billiald, P.; Gachet, C.; Jandrot-Perrus, M. The future of glycoprotein VI as an antithrombotic target. J. Thromb. Haemost. 2012, 10, 2418-2427. [CrossRef] [PubMed]

24. Nurden, A.T. Clinical significance of altered collagen-receptor functioning in platelets with emphasis on glycoprotein VI. Blood Rev. 2019, 38, 100592. [CrossRef]

25. Kunicki, T.J.; Cheli, Y.; Moroi, M.; Furihata, K. The influence of N-linked glycosylation on the function of platelet glycoprotein VI. Blood 2005, 106, 2744-2749. [CrossRef] [PubMed]

26. Montague, S.J.; Andrews, R.K.; Gardiner, E.E. Mechanisms of receptor shedding in platelets. Blood 2018, 132, 2535-2545. [CrossRef]

27. Bender, M.; Hofmann, S.; Stegner, D.; Chalaris, A.; Bosl, M.; Braun, A.; Scheller, J.; Rose-John, S.; Nieswandt, B. Differentially regulated GPVI ectodomain shedding by multiple platelet-expressed proteinases. Blood 2010, 116, 3347-3355. [CrossRef]

28. Escrevente, C.; Morais, V.A.; Keller, S.; Soares, C.M.; Altevogt, P.; Costa, J. Functional role of N-glycosylation from ADAM10 in processing, localization and activity of the enzyme. Biochim. Biophys. Acta 2008, 1780, 905-913. [CrossRef] [PubMed]

29. Suzuki-Inoue, K.; Inoue, O.; Ozaki, Y. Novel platelet activation receptor CLEC-2: From discovery to prospects. J. Thromb. Haemost. 2011, 9, 44-55. [CrossRef] [PubMed]

30. Zhou, L.; Qian, Y.; Zhang, X.; Ruan, Y.; Ren, S.; Gu, J. Elucidation of differences in N-glycosylation between different molecular weight forms of recombinant CLEC-2 by LC MALDI tandem MS. Carbohydr. Res. 2015, 402, 180-188. [CrossRef]

31. Nurden, A.T. Platelet membrane glycoproteins: A historical review. Semin. Thromb. Hemost. 2014, 40, 577-584. [CrossRef]

32. Savoia, A.; Kunishima, S.; De Rocco, D.; Zieger, B.; Rand, M.L.; Pujol-Moix, N.; Caliskan, U.; Tokgoz, H.; Pecci, A.; Noris, P.; et al. Spectrum of the mutations in Bernard-Soulier syndrome. Hum. Mutat. 2014, 35, 1033-1045. [CrossRef]

33. Ulsemer, P.; Strassel, C.; Baas, M.J.; Salamero, J.; Chasserot-Golaz, S.; Cazenave, J.P.; Lanza, F.; De La Salle, C. Biosynthesis and intracellular post-translational processing of normal and mutant platelet glycoprotein GPIb-IX. Biochem. J. 2001, 358, 295-303. [CrossRef]

34. Hoffmeister, K.M.; Felbinger, T.W.; Falet, H.; Denis, C.V.; Bergmeier, W.; Mayadas, T.N.; von Andrian, U.H.; Wagner, D.D.; Stossel, T.P.; Hartwig, J.H. The clearance mechanism of chilled blood platelets. Cell 2003, 112, 87-97. [CrossRef]

35. Hoffmeister, K.M.; Josefsson, E.C.; Isaac, N.A.; Clausen, H.; Hartwig, J.H.; Stossel, T.P. Glycosylation restores survival of chilled blood platelets. Science 2003, 301, 1531-1534. [CrossRef]

36. Lanza, F.; Morales, M.; de La Salle, C.; Cazenave, J.P.; Clemetson, K.J.; Shimomura, T.; Phillips, D.R. Cloning and characterization of the gene encoding the human platelet glycoprotein V. A member of the leucine-rich glycoprotein family cleaved during thrombin-induced platelet activation. J. Biol. Chem. 1993, 268, 20801-20807.

37. Li, R.; Hoffmeister, K.M.; Falet, H. Glycans and the platelet life cycle. Platelets 2016, 27, 505-511. [CrossRef] 
38. Mo, X.; Nguyen, N.X.; McEwan, P.A.; Zheng, X.; Lopez, J.A.; Emsley, J.; Li, R. Binding of platelet glycoprotein Ibbeta through the convex surface of leucine-rich repeats domain of glycoprotein IX. J. Thromb. Haemost. 2009, 7, 1533-1540. [CrossRef]

39. Kitaguchi, T.; Murata, M.; Ambo, H.; Ikeda, Y. Characterization of cDNA encoding full-length mouse platelet glycoprotein IX. Blood Coagul Fibrinolysis 1998, 9, 381-385. [CrossRef]

40. Gurbel, P.A.; Kuliopulos, A.; Tantry, U.S. G-protein-coupled receptors signaling pathways in new antiplatelet drug development. Arter. Thromb. Vasc. Biol. 2015, 35, 500-512. [CrossRef]

41. Offermanns, S. Activation of platelet function through G protein-coupled receptors. Circ. Res. 2006, 99, 1293-1304. [CrossRef]

42. Gachet, C.; Leon, C.; Hechler, B. The platelet P2 receptors in arterial thrombosis. Blood Cells Mol. Dis. 2006, 36, 223-227. [CrossRef]

43. Gachet, C.; Hechler, B. The platelet P2 receptors in thrombosis. Semin. Thromb. Hemost. 2005, 31, 162-167. [CrossRef]

44. Murugappa, S.; Kunapuli, S.P. The role of ADP receptors in platelet function. Front. Biosci. 2006, 11, 1977-1986. [CrossRef]

45. Fabre, J.E.; Nguyen, M.; Latour, A.; Keifer, J.A.; Audoly, L.P.; Coffman, T.M.; Koller, B.H. Decreased platelet aggregation, increased bleeding time and resistance to thromboembolism in P2Y1-deficient mice. Nat. Med. 1999, 5, 1199-1202. [CrossRef]

46. Leon, C.; Hechler, B.; Freund, M.; Eckly, A.; Vial, C.; Ohlmann, P.; Dierich, A.; LeMeur, M.; Cazenave, J.P.; Gachet, C. Defective platelet aggregation and increased resistance to thrombosis in purinergic P2Y(1) receptor-null mice. J. Clin. Investig. 1999, 104, 1731-1737. [CrossRef]

47. Foster, C.J.; Prosser, D.M.; Agans, J.M.; Zhai, Y.; Smith, M.D.; Lachowicz, J.E.; Zhang, F.L.; Gustafson, E.; Monsma, F.J., Jr.; Wiekowski, M.T.; et al. Molecular identification and characterization of the platelet ADP receptor targeted by thienopyridine antithrombotic drugs. J. Clin. Investig. 2001, 107, 1591-1598. [CrossRef]

48. Andre, P.; Delaney, S.M.; LaRocca, T.; Vincent, D.; DeGuzman, F.; Jurek, M.; Koller, B.; Phillips, D.R.; Conley, P.B. P2Y12 regulates platelet adhesion/activation, thrombus growth, and thrombus stability in injured arteries. J. Clin. Investig. 2003, 112, 398-406. [CrossRef] [PubMed]

49. Zhong, X.; Kriz, R.; Seehra, J.; Kumar, R. N-linked glycosylation of platelet P2Y12 ADP receptor is essential for signal transduction but not for ligand binding or cell surface expression. FEBS Lett. 2004, 562, 111-117. [CrossRef]

50. Coughlin, S.R. Protease-activated receptors in hemostasis, thrombosis and vascular biology. J. Thromb. Haemost. 2005, 3, 1800-1814. [CrossRef]

51. Landis, R.C. Protease activated receptors: Clinical relevance to hemostasis and inflammation. Hematol. Clin. North Am. 2007, 21, 103-113. [CrossRef]

52. Nieman, M.T. Protease-activated receptors in hemostasis. Blood 2016, 128, 169-177. [CrossRef] [PubMed]

53. Soto, A.G.; Trejo, J. N-linked glycosylation of protease-activated receptor-1 second extracellular loop: A critical determinant for ligand-induced receptor activation and internalization. J. Biol. Chem. 2010, 285, 18781-18793. [CrossRef]

54. Varga-Szabo, D.; Braun, A.; Nieswandt, B. Calcium signaling in platelets. J. Thromb. Haemost. 2009, 7, 1057-1066. [CrossRef]

55. Mammadova-Bach, E.; Nagy, M.; Heemskerk, J.W.M.; Nieswandt, B.; Braun, A. Store-operated calcium entry in thrombosis and thrombo-inflammation. Cell Calcium 2019, 77, 39-48. [CrossRef] [PubMed]

56. Hofmann, T.; Obukhov, A.G.; Schaefer, M.; Harteneck, C.; Gudermann, T.; Schultz, G. Direct activation of human TRPC6 and TRPC3 channels by diacylglycerol. Nature 1999, 397, 259-263. [CrossRef]

57. Hechler, B.; Gachet, C. Purinergic receptors in thrombosis and inflammation. Arter. Thromb. Vasc. Biol. 2015, 35, 2307-2315. [CrossRef]

58. Gachet, C.; Hechler, B. Platelet purinergic receptors in thrombosis and inflammation. Hämostaseologie 2020, 40, 145-152.

59. Rettinger, J.; Aschrafi, A.; Schmalzing, G. Roles of individual N-glycans for ATP potency and expression of the rat P2X1 receptor. J. Biol. Chem. 2000, 275, 33542-33547. [CrossRef]

60. Roberts, J.A.; Evans, R.J. Contribution of conserved polar glutamine, asparagine and threonine residues and glycosylation to agonist action at human P2X1 receptors for ATP. J. Neurochem. 2006, 96, 843-852. [CrossRef] 
61. Dietrich, A. Modulators of transient receptor potential (TRP) channels as therapeutic options in lung disease. Pharmaceuticals 2019, 12, 23. [CrossRef] [PubMed]

62. Hassock, S.R.; Zhu, M.X.; Trost, C.; Flockerzi, V.; Authi, K.S. Expression and role of TRPC proteins in human platelets: Evidence that TRPC6 forms the store-independent calcium entry channel. Blood 2002, 100, 2801-2811. [CrossRef] [PubMed]

63. Dietrich, A.; Gudermann, T. TRPC6: Physiological function and pathophysiological relevance. In Handbook of Experimental Pharmacology; Springer: New York, NY, USA, 2014; pp. 157-188.

64. Dietrich, A.; Mederos y Schnitzler, M.; Emmel, J.; Kalwa, H.; Hofmann, T.; Gudermann, T. N-linked protein glycosylation is a major determinant for basal TRPC3 and TRPC6 channel activity. J. Biol. Chem. 2003, 278, 47842-47852. [CrossRef]

65. Braun, A.; Vogtle, T.; Varga-Szabo, D.; Nieswandt, B. STIM and Orai in hemostasis and thrombosis. Front. Biosci. 2011, 16, 2144-2160. [CrossRef]

66. Grosse, J.; Braun, A.; Varga-Szabo, D.; Beyersdorf, N.; Schneider, B.; Zeitlmann, L.; Hanke, P.; Schropp, P.; Muhlstedt, S.; Zorn, C.; et al. An EF hand mutation in Stim1 causes premature platelet activation and bleeding in mice. J. Clin. Investig. 2007, 117, 3540-3550. [CrossRef]

67. Braun, A.; Varga-Szabo, D.; Kleinschnitz, C.; Pleines, I.; Bender, M.; Austinat, M.; Bosl, M.; Stoll, G.; Nieswandt, B. Orai1 (CRACM1) is the platelet SOC channel and essential for pathological thrombus formation. Blood 2009, 113, 2056-2063. [CrossRef]

68. Choi, Y.J.; Zhao, Y.; Bhattacharya, M.; Stathopulos, P.B. Structural perturbations induced by Asn131 and Asn171 glycosylation converge within the EFSAM core and enhance stromal interaction molecule-1 mediated store operated calcium entry. Biochim. Biophys. Acta Mol. Cell Res. 2017, 1864, 1054-1063. [CrossRef]

69. Kramer, P.A.; Ravi, S.; Chacko, B.; Johnson, M.S.; Darley-Usmar, V.M. A review of the mitochondrial and glycolytic metabolism in human platelets and leukocytes: Implications for their use as bioenergetic biomarkers. Redox. Biol. 2014, 2, 206-210. [CrossRef]

70. Aibibula, M.; Naseem, K.M.; Sturmey, R.G. Glucose metabolism and metabolic flexibility in blood platelets. J. Thromb. Haemost. 2018, 16, 2300-2314. [CrossRef]

71. Craik, J.D.; Stewart, M.; Cheeseman, C.I. GLUT-3 (brain-type) glucose transporter polypeptides in human blood platelets. Thromb. Res. 1995, 79, 461-469. [CrossRef]

72. Heijnen, H.F.; Oorschot, V.; Sixma, J.J.; Slot, J.W.; James, D.E. Thrombin stimulates glucose transport in human platelets via the translocation of the glucose transporter GLUT-3 from alpha-granules to the cell surface. J. Cell Biol. 1997, 138, 323-330. [CrossRef] [PubMed]

73. Fidler, T.P.; Campbell, R.A.; Funari, T.; Dunne, N.; Balderas Angeles, E.; Middleton, E.A.; Chaudhuri, D.; Weyrich, A.S.; Abel, E.D. Deletion of GLUT1 and GLUT3 Reveals Multiple Roles for Glucose Metabolism in Platelet and Megakaryocyte Function. Cell Rep. 2017, 20, 881-894. [CrossRef]

74. Mueckler, M.; Thorens, B. The SLC2 (GLUT) family of membrane transporters. Mol. Asp. Med. 2013, 34, 121-138. [CrossRef] [PubMed]

75. Asano, T.; Katagiri, H.; Takata, K.; Lin, J.L.; Ishihara, H.; Inukai, K.; Tsukuda, K.; Kikuchi, M.; Hirano, H.; Yazaki, Y.; et al. The role of N-glycosylation of GLUT1 for glucose transport activity. J. Biol. Chem. 1991, 266, 24632-24636. [PubMed]

76. Asano, T.; Takata, K.; Katagiri, H.; Ishihara, H.; Inukai, K.; Anai, M.; Hirano, H.; Yazaki, Y.; Oka, Y. The role of N-glycosylation in the targeting and stability of GLUT1 glucose transporter. FEBS Lett. 1993, 324, 258-261. [CrossRef]

77. Samih, N.; Hovsepian, S.; Notel, F.; Prorok, M.; Zattara-Cannoni, H.; Mathieu, S.; Lombardo, D.; Fayet, G.; El-Battari, A. The impact of $\mathrm{N}$ - and O-glycosylation on the functions of Glut-1 transporter in human thyroid anaplastic cells. Biochim. Biophys. Acta 2003, 1621, 92-101. [CrossRef]

78. Blommaert, E.; Peanne, R.; Cherepanova, N.A.; Rymen, D.; Staels, F.; Jaeken, J.; Race, V.; Keldermans, L.; Souche, E.; Corveleyn, A.; et al. Mutations in MAGT1 lead to a glycosylation disorder with a variable phenotype. Proc. Natl. Acad. Sci. USA 2019, 116, 9865-9870. [CrossRef]

79. Cherepanova, N.A.; Gilmore, R. Mammalian cells lacking either the cotranslational or posttranslocational oligosaccharyltransferase complex display substrate-dependent defects in asparagine linked glycosylation. Sci. Rep. 2016, 6, 20946. [CrossRef] 
80. Matsuda-Lennikov, M.; Biancalana, M.; Zou, J.; Ravell, J.C.; Zheng, L.; Kanellopoulou, C.; Jiang, P.; Notarangelo, G.; Jing, H.; Masutani, E.; et al. Magnesium transporter 1 (MAGT1) deficiency causes selective defects in N-linked glycosylation and expression of immune-response genes. J. Biol. Chem. 2019, 294, 13638-13656. [CrossRef]

81. Vaeth, M.; Maus, M.; Klein-Hessling, S.; Freinkman, E.; Yang, J.; Eckstein, M.; Cameron, S.; Turvey, S.E.; Serfling, E.; Berberich-Siebelt, F.; et al. Store-Operated Ca(2+) Entry Controls Clonal Expansion of T Cells through Metabolic Reprogramming. Immunity 2017, 47, 664-679. [CrossRef]

82. Blair, P.; Flaumenhaft, R. Platelet alpha-granules: Basic biology and clinical correlates. Blood Rev. 2009, 23, 177-189. [CrossRef]

83. Ghoshal, P.; Rajendran, M.; Odo, N.; Ikuta, T. Glycosylation inhibitors efficiently inhibit P-selectin-mediated cell adhesion to endothelial cells. PLoS ONE 2014, 9, e99363. [CrossRef]

84. Quinsey, N.S.; Greedy, A.L.; Bottomley, S.P.; Whisstock, J.C.; Pike, R.N. Antithrombin: In control of coagulation. Int. J. Biochem. Cell Biol. 2004, 36, 386-389. [CrossRef]

85. Peterson, C.B.; Blackburn, M.N. Isolation and characterization of an antithrombin III variant with reduced carbohydrate content and enhanced heparin binding. J. Biol. Chem. 1985, 260, 610-615. [PubMed]

86. McCoy, A.J.; Pei, X.Y.; Skinner, R.; Abrahams, J.P.; Carrell, R.W. Structure of beta-antithrombin and the effect of glycosylation on antithrombin's heparin affinity and activity. J. Mol. Biol. 2003, 326, 823-833. [CrossRef]

87. Clerc, F.; Reiding, K.R.; Jansen, B.C.; Kammeijer, G.S.; Bondt, A.; Wuhrer, M. Human plasma protein N-glycosylation. Glycoconj. J. 2016, 33, 309-343. [CrossRef] [PubMed]

88. Shigekiyo, T.; Kanazuka, M.; Azuma, H.; Ohshima, T.; Kusaka, K.; Saito, S. Congenital deficiency of histidine-rich glycoprotein: Failure to identify abnormalities in routine laboratory assays of hemostatic function, immunologic function, and trace elements. J. Lab Clin. Med. 1995, 125, 719-723. [PubMed]

89. Shigekiyo, T.; Ohshima, T.; Oka, H.; Tomonari, A.; Azuma, H.; Saito, S. Congenital histidine-rich glycoprotein deficiency. Thromb. Haemost. 1993, 70, 263-265. [CrossRef] [PubMed]

90. Isordia-Salas, I.; Pixley, R.A.; Parekh, H.; Kunapuli, S.P.; Li, F.; Stadnicki, A.; Lin, Y.; Sartor, R.B.; Colman, R.W. The mutation Ser511Asn leads to N-glycosylation and increases the cleavage of high molecular weight kininogen in rats genetically susceptible to inflammation. Blood 2003, 102, 2835-2842. [CrossRef]

91. Bryant, J.W.; Shariat-Madar, Z. Human plasma kallikrein-kinin system: Physiological and biochemical parameters. Cardiovasc. Hematol. Agents Med. Chem. 2009, 7, 234-250. [CrossRef]

92. Bolt, G.; Steenstrup, T.D.; Kristensen, C. All post-translational modifications except propeptide cleavage are required for optimal secretion of coagulation factor VII. Thromb. Haemost. 2007, 98, 988-997. [PubMed]

93. Bolt, G.; Kristensen, C.; Steenstrup, T.D. Posttranslational N-glycosylation takes place during the normal processing of human coagulation factor VII. Glycobiology 2004, 15, 541-547. [CrossRef] [PubMed]

94. Mohammed, B.M.; Matafonov, A.; Ivanov, I.; Sun, M.F.; Cheng, Q.; Dickeson, S.K.; Li, C.; Sun, D.; Verhamme, I.M.; Emsley, J.; et al. An update on factor XI structure and function. Thromb. Res. 2018, 161, 94-105. [CrossRef]

95. Faid, V.; Denguir, N.; Chapuis, V.; Bihoreau, N.; Chevreux, G. Site-specific N-glycosylation analysis of human factor XI: Identification of a noncanonical NXC glycosite. Proteomics 2014, 14, 2460-2470. [CrossRef]

96. Canis, K.; McKinnon, T.A.; Nowak, A.; Haslam, S.M.; Panico, M.; Morris, H.R.; Laffan, M.A.; Dell, A. Mapping the N-glycome of human von Willebrand factor. Biochem. J. 2012, 447, 217-228. [CrossRef] [PubMed]

97. McKinnon, T.A.; Goode, E.C.; Birdsey, G.M.; Nowak, A.A.; Chan, A.C.; Lane, D.A.; Laffan, M.A. Specific N-linked glycosylation sites modulate synthesis and secretion of von Willebrand factor. Blood 2010, 116, 640-648. [CrossRef] [PubMed]

98. Crawley, J.T.; de Groot, R.; Xiang, Y.; Luken, B.M.; Lane, D.A. Unraveling the scissile bond: How ADAMTS13 recognizes and cleaves von Willebrand factor. Blood 2011, 118, 3212-3221. [CrossRef]

99. McKinnon, T.A.; Chion, A.C.; Millington, A.J.; Lane, D.A.; Laffan, M.A. N-linked glycosylation of VWF modulates its interaction with ADAMTS13. Blood 2008, 111, 3042-3049. [CrossRef] [PubMed]

100. Zhou, W.; Tsai, H.M. N-Glycans of ADAMTS13 modulate its secretion and von Willebrand factor cleaving activity. Blood 2009, 113, 929-935. [CrossRef] [PubMed]

101. Chang, I.J.; He, M.; Lam, C.T. Congenital disorders of glycosylation. Ann. Transl. Med. 2018, 6, 477. [CrossRef] [PubMed] 
102. Verheijen, J.; Tahata, S.; Kozicz, T.; Witters, P.; Morava, E. Therapeutic approaches in Congenital Disorders of Glycosylation (CDG) involving N-linked glycosylation: An update. Genet. Med. 2020, 22, 268-279. [CrossRef] [PubMed]

103. Makhamreh, M.M.; Cottingham, N.; Ferreira, C.R.; Berger, S.; Al-Kouatly, H.B. Nonimmune hydrops fetalis and congenital disorders of glycosylation: A systematic literature review. J. Inherit. Metab. Dis. 2020, 43, 223-233. [CrossRef] [PubMed]

104. Ng, B.G.; Shiryaev, S.A.; Rymen, D.; Eklund, E.A.; Raymond, K.; Kircher, M.; Abdenur, J.E.; Alehan, F.; Midro, A.T.; Bamshad, M.J.; et al. ALG1-CDG: Clinical and Molecular Characterization of 39 Unreported Patients. Hum. Mutat. 2016, 37, 653-660. [CrossRef] [PubMed]

105. Morava, E.; Tiemes, V.; Thiel, C.; Seta, N.; de Lonlay, P.; de Klerk, H.; Mulder, M.; Rubio-Gozalbo, E.; Visser, G.; van Hasselt, P.; et al. ALG6-CDG: A recognizable phenotype with epilepsy, proximal muscle weakness, ataxia and behavioral and limb anomalies. J. Inherit. Metab. Dis. 2016, 39, 713-723. [CrossRef] [PubMed]

106. Hock, M.; Wegleiter, K.; Ralser, E.; Kiechl-Kohlendorfer, U.; Scholl-Burgi, S.; Fauth, C.; Steichen, E.; Pichler, K.; Lefeber, D.J.; Matthjis, G.; et al. ALG8-CDG: Novel patients and review of the literature. Orphanet J. Rare Dis. 2015, 10, 73. [CrossRef]

107. Li, F.Y.; Chaigne-Delalande, B.; Kanellopoulou, C.; Davis, J.C.; Matthews, H.F.; Douek, D.C.; Cohen, J.I.; Uzel, G.; Su, H.C.; Lenardo, M.J. Second messenger role for Mg2+ revealed by human T-cell immunodeficiency. Nature 2011, 475, 471-476. [CrossRef]

108. Li, F.Y.; Chaigne-Delalande, B.; Su, H.; Uzel, G.; Matthews, H.; Lenardo, M.J. XMEN disease: A new primary immunodeficiency affecting $\mathrm{Mg} 2+$ regulation of immunity against Epstein-Barr virus. Blood 2014, 123, 2148-2152. [CrossRef]

109. Chaigne-Delalande, B.; Li, F.Y.; O'Connor, G.M.; Lukacs, M.J.; Jiang, P.; Zheng, L.; Shatzer, A.; Biancalana, M.; Pittaluga, S.; Matthews, H.F.; et al. Mg2+ regulates cytotoxic functions of NK and CD8 T cells in chronic EBV infection through NKG2D. Science 2013, 341, 186-191. [CrossRef]

110. Zhou, H.; Clapham, D.E. Mammalian MagT1 and TUSC3 are required for cellular magnesium uptake and vertebrate embryonic development. Proc. Natl. Acad. Sci. USA 2009, 106, 15750-15755. [CrossRef]

111. Feske, S.; Wulff, H.; Skolnik, E.Y. Ion channels in innate and adaptive immunity. Annu. Rev. Immunol. 2015, 33, 291-353. [CrossRef]

112. Ravell, J.; Chaigne-Delalande, B.; Lenardo, M. X-linked immunodeficiency with magnesium defect, Epstein-Barr virus infection, and neoplasia disease: A combined immune deficiency with magnesium defect. Curr. Opin. Pediatr. 2014, 26, 713-719. [CrossRef]

113. Ravell, J.C.; Matsuda-Lennikov, M.; Chauvin, S.D.; Zou, J.; Biancalana, M.; Deeb, S.J.; Price, S.; Su, H.C.; Notarangelo, G.; Jiang, P.; et al. Defective glycosylation and multisystem abnormalities characterize the primary immunodeficiency XMEN disease. J. Clin. Investig. 2020, 130, 507-522. [CrossRef] [PubMed]

114. Mammadova-Bach, E.; Gotru, S.K.; Schuhmann, M.K.; Wolf, K.; Kraft, P.; Herterich, S.; Stritt, S.; Remer, K.; Beck, S.; Swieringa, F.; et al. Hemostatic and Non-hemostatic Functions of Magnesium Transporter MAGT1 in Mice. ISTH 2019. Oral communication.

115. Hwang, D.L.; Yen, C.F.; Nadler, J.L. Effect of extracellular magnesium on platelet activation and intracellular calcium mobilization. Am. J. Hypertens. 1992, 5, 700-706. [CrossRef] [PubMed]

116. Jaeken, J.; Lefeber, D.; Matthijs, G. Clinical utility gene card for: Phosphomannose isomerase deficiency. Eur. J. Hum. Genet. 2014, 22, 1153. [CrossRef]

117. Liem, Y.S.; Bode, L.; Freeze, H.H.; Leebeek, F.W.; Zandbergen, A.A.; Paul Wilson, J. Using heparin therapy to reverse protein-losing enteropathy in a patient with CDG-Ib. Nat. Clin. Pract. Gastroenterol. Hepatol. 2008, 5, 220-224. [CrossRef]

118. Van Geet, C.; Jaeken, J.; Freson, K.; Lenaerts, T.; Arnout, J.; Vermylen, J.; Hoylaerts, M.F. Congenital disorders of glycosylation type Ia and IIa are associated with different primary haemostatic complications. J. Inherit. Metab. Dis. 2001, 24, 477-492. [CrossRef]

119. de la Morena-Barrio, M.E.; Di Michele, M.; Lozano, M.L.; Rivera, J.; Perez-Duenas, B.; Altisent, C.; Sevivas, T.; Vicente, V.; Jaeken, J.; Freson, K.; et al. Proteomic analysis of platelet N-glycoproteins in PMM2-CDG patients. Thromb. Res. 2014, 133, 412-417. [CrossRef]

120. Mohamed, M.; Ashikov, A.; Guillard, M.; Robben, J.H.; Schmidt, S.; van den Heuvel, B.; de Brouwer, A.P.; Gerardy-Schahn, R.; Deen, P.M.; Wevers, R.A.; et al. Intellectual disability and bleeding diathesis due to deficient CMP—Sialic acid transport. Neurology 2013, 81, 681-687. [CrossRef] 
121. Ng, B.G.; Asteggiano, C.G.; Kircher, M.; Buckingham, K.J.; Raymond, K.; Nickerson, D.A.; Shendure, J.; Bamshad, M.J.; University of Washington Center for Mendelian, G.; Ensslen, M.; et al. Encephalopathy caused by novel mutations in the CMP-sialic acid transporter, SLC35A1. Am. J. Med. Genet. A 2017, 173, 2906-2911. [CrossRef]

122. Kauskot, A.; Pascreau, T.; Adam, F.; Bruneel, A.; Reperant, C.; Lourenco-Rodrigues, M.D.; Rosa, J.P.; Petermann, R.; Maurey, H.; Auditeau, C.; et al. A mutation in the gene coding for the sialic acid transporter SLC35A1 is required for platelet life span but not proplatelet formation. Haematologica 2018, 103, e613-e617. [CrossRef] [PubMed]

123. Ma, X.; Li, Y.; Kondo, Y.; Shi, H.; Han, J.; Jiang, Y.; Bai, X.; Archer-Hartmann, S.A.; Azadi, P.; Ruan, C.; et al. Slc35a1 deficiency causes thrombocytopenia due to impaired megakaryocytopoiesis and excessive platelet clearance in the liver. Haematologica 2020. [CrossRef] [PubMed]

124. Chang, I.J.; Byers, H.M.; Ng, B.G.; Merritt, J.L., 2nd; Gilmore, R.; Shrimal, S.; Wei, W.; Zhang, Y.; Blair, A.B.; Freeze, H.H.; et al. Factor VIII and vWF deficiency in STT3A-CDG. J. Inherit. Metab. Dis. 2019, 42, 325-332. [CrossRef] [PubMed]

(C) 2020 by the authors. Licensee MDPI, Basel, Switzerland. This article is an open access article distributed under the terms and conditions of the Creative Commons Attribution (CC BY) license (http://creativecommons.org/licenses/by/4.0/). 